\title{
FORM-MAKING METHODS IN LANDFORM ARCHITECTURE
}

Scientific paper

(Received: 24 May 2020; accepted: 23 September 2020)

\section{Yana Kuznietsova}

Department of buildings, structures and design of the architectural environment; Faculty of Architecture, Design and Fine Arts; O.M. Beketov National University of Urban Economy in Kharkiv, Assistant Professor

Corresponding author: yana.arch.de@gmail.com

\section{Halyna Osychenko}

Department of buildings, structures and design of the architectural environment; Faculty of Architecture, Design and Fine Arts; O.M. Beketov National University of Urban Economy in Kharkiv, PhD in Architecture, Professor

\begin{abstract}
In this study, we consider a critical challenge in architectural design methodology-methods of form making in landform architecture. Based on the authors' methodology, the approaches and methods of form making are specified and systematized, depending on the algorithm of the form-making process and the basic principles of building composition. The approaches to architectural form making, including image-based, generative, and functional approaches are determined. The methods within the framework of the image-based approach are identified. These methods include natural «mimicry» and metaphorical methods, as well asan image-based and combinatorial method. Furthermore, the principles and techniques of form-making methods are examined, and their capability and potential to create esthetically expressive and poetically shaped buildings, which can be integrated into existing natural landscapes, are determined.
\end{abstract}

Keywords: Landform architecture; natural "mimicry" method; metaphorical method; image-based and combinatorial method; stylization. 


\section{INTRODUCTION}

The global environmental crisis has led to a rethink of current approaches to architecture and the need foralterations in ecologically cohesive architecture and design methods, including "sustainable, "landform", green, and watermorphic architectures, as well as architecture of "Earth houses," etc.

In Russian and Ukrainian architectural theories, the novel ecological approaches in architecture that actively adopt natural components (water, vegetation, soil) in form making are generally called "nature-integrated architecture" (V. Logvinov, 2009). Among these approaches, western researchers pay special attention to landform architecture (term introduced by C. Jencks, 1997), a new approach that combines architectural forms with natural topographies into a coherent and consistent system. The development of this approach started in the beginning of the 1990s owing to experiments conducted with folding, surface manipulation, and artificial relief creation within the framework of landscape urbanism. Presently, this approach is one of the most interesting in modern architecture, as it combines methods and achievements of architecture, landscape architecture, and urban planning. It is represented in the works of the following architects: E. Ambasz (Argentina), P. Vetsch (Switzerlalnd), K. Yeang (Malaysia), M. Sorkin (USA), M. Fuksas (Italy), F. Hundertwasser (Vienna), M. Vermeulen (Netherlands), O. Drozdov (Ukraine), M. Budzynski, Z. Badowski (Poland), B. Radonić, and G. Rako (Croatia). The following projects on architectural groups and offices have been studied: greenovergray, Alarcon + Asociados, IMOCOM, Skylab Architecture, Bjarke Ingels Group (BIG), Archicura, MVRDV, WOHA, VenhoevenCS, Mass Studio, Aedas, A+A, Galabau, Florafelt, Wall of flowers, architectural office FAAB, Snøhetta, and GLUCK+.

Landform architectural objects, in turn, have garnered significant attention in the research and debates among the following theorists: E. Ambasz [1], S. Allen and M. McQuade [2], D. Balmori and J. Sanders [3], C. Jencks [4], Ph. Jodidio [5], D. Leatherbarrow [6], R. Sterling [7], J. Wines [8], H. Xiaoning [9,10], Yi Wang [11], M. Zambelli [12], etc.

This research is devoted to the study of landform architecture form-making methods. Owing to the rapid increase in the number of nature-integrated objects and the development of environmental trends in architecture, it is necessary to study such a crucial architectural design issue as methods of architectural form-making. In the face of an ecological crisis and development of new design technologies, the development of architecture and urban planning is faced with the challenge of a lack of conventional form-making methods for solving non-trivial problems that do not have rigidly defined conditions and parameters. The development of compositional thinking, discovery of possibilities in form-making methods and techniques, search for composition patterns, and study of previous experience constitute an integral part of professional training and development of the creative abilities and skills of architects, which emphasizes the relevance of this research.

The tasks in this research include systemizing methods and approaches, analyzing form-making methods, and defining features of their application in landform architecture. The object of this study is landform architecture while the subject includes the methods and techniques of architectural form making in landform architecture. The image-based methods are analyzed in this paper. This study focuses on the formal aspects of the subject, thus the semantics of forms and philosophical make up of form making need special attention and remain beyond the scope of this article.

\section{THEORETICAL FOUNDATION OF THE RESEARCH AND ANALYSIS OF RECENT PUBLICATIONS}

The theoretical foundation of this study is based on a research divided into two groups. The first group involves a study on various aspects of natural and architectural object integration by foreign and post-Soviet authors: $F$. Wright [13], J. Simonds [14], R. Thomas [15], A. Know and W. Grondzik [16], K. Luckett [17] (USA), P. Portoghesi [18] (Italy), V. Nefedov [19], A. Zaslavska [20] (Russia), H. Osychenko [21], D. Chyzhmak [22], and I. Volynets [23] (Ukraine). The works of the following scientists are devoted to the study of nature-integrated architectural objects: V. Logvinov [24] (Russia), N. Kryzhanivska [25], Y. Hordienko [26], O. Smirnova and M. Votinov [27] (Ukraine); K. Murenkova [28] (Kazakhstan), B. Tomkovych [29], M. Gala-Valchovska [30], E. Kusinska [31], P. Haupt [32], M. Kmych [33], M. Zhezotarska-Palka [34] (Poland), M. Zbašnik-Senegaènik and M. Kuzman [35], 
and M. Mustapić and A. Vlahov [36]) (Croatia). However, in the methods proposed in these studies, architectural form making via natural components was not fully considered.

The second research group is devoted to the study of classical and modern methods of architectural form making, conducted by I. Dobritsina [37]- philosophical understanding of the idea of nonlinearity in architecture (nonlinear or parametric method); O. Kashchenko [38]- form making in design and architecture based on modeling bioprototypes; Yu. Lebedev and V. Rabinovich [39] (bionic method in architecture); E. Pronin [40] (combinatorial method); N. Shapoval [41] (overhead facade method, classical, sculptural and structural methods), as well as J. Frazer [42], N. Oxman [43], P. Schumacher [44], and K. Terzidis [45] (generative approach and parametric method). Because the application of form-making methods is inseparable from the challenges facing architectural composition, studies on the composition theory, namely the works of F. D. K. Ching [46], O. Tits [47], A. Ikonnikov, and G. Stepanov [48], were considered. Among the works devoted to metaphorical theory, method, and architecture, the works of Basil Al Bayati [49], B. Fez-Barringten [50], K. Karatani [51], and A. Ortoni [52], were distinguished. Acoording to the book authored by M. Zambelli [53], we considered analogy and metaphor as cognitive mechanisms that are fundamental to creative activity in architecture and design.

It should be noted that within the framework of the mentioned studies, the methods of nature-integrated architecture were not directly considered, and the peculiarities of their application in landform architecture were not determined. In general, there is an understanding gap in the compositional aspect and form making methods of nature-integrated architectural objects.

\section{METHODS OF RESEARCH}

The main method adopted in this study is the compositional-formal method of building analysis. From its perspective, the perceived architectural object is a combination of regular spatial relationships. Formal analysis examines the elements that make up the artistic entirety; as well as laws or principles according to which they are combined [54, p. 26]. This study also adopts fundamental scientific methods and techniques (analysis and synthesis, comparison, abstraction, systematization, etc.), including the basic points of a systematic approach.

In the study of nature-integrated architecture, we considered the building as a complex system that includes subsystems (spatial, structural, engineering, communication, functional and planning subsystems, subsystems of external fences, subsystems of details and building decor, and subsystems of building and decoration materials), which are interconnected to form the exterior shape of the object and its three-dimensional composition (TDC). Spatial composition determines the image of the building.

By generalizing existing research, the authors have developed a comprehensive technique for analyzing the architectural form making of buildings, which combines the formal compositional analysis of the building with identifying the creative process of morphogenesis, which involves studying the author's concepts and texts. Furthermore, it includes several stages. The first stage is the author's approach to studying object form making, which allows us to reproduce the sequence of form making, discover the idea and concept images, as well as determine the original prototype of the architectural form. The drawings, concepts, pictures and works of authors, literary sources, including theoretical and critical articles on architectural objects are analyzed. The second stageinvolves identifying building subsystems, defining the rules and principles of interaction between building subsystems, and determining the dominant subsystem and methods of reflecting it on the external form of the building. The third stage involves the formal-compositional analysis of an object at all scale levels, which includes identifying the basic form of the object, characterizing the archetypal base planes (roof, wall, floor), analyzing the transformation techniques of the basic form and blended forms, defining the principles and methods of TDC construction and its nature, as well as defining the rules and methods of the facade element arrangement. The fourth stage involves identifying the methods for the application of natural components in the building form making process at all scale levels of the object, as determined by its levels of perception. The fifth stage involves identifying the form-making method, including comparative analysis with existing methods, summarizing the analysis, and defining the method, its procedure, principles, and specific rules.

Approximately 300 objects of nature-integrated architecture were analyzed. Based on the earliermentioned methodology and analysis of the form-making methods created by previous studies, the approaches and methods of architectural form making have been presented. The creativity of architects is relativelya synthesis of the creative methods of artists, scientists, and engineers. Although intuition plays a significant role in creativity, architects replicate their techniques and methods in their working processes, and the laws that govern the

Kuznietsova, Y, Osychenko, $\mathrm{H}$ 
creation of the object's project model guidethe author. Therefore, we consider the method to be a process of selecting and assembling the elements and subsystems of a building into a single composite integrity, which relies on certain organizational logic, ideas, and principles for creating architectural forms. Among them are the following: a) algorithm and sequence of the form making process, (primary basis), b) rules and principles for interaction between building subsystems, c) selection of a dominant subsystem (or subsystems) with its (or their) display and articulation on the exterior of the building, d) the presence of specific methods of form making, and e) establishing certain rules and principles for the interaction between the elements of the form.

Depending on the sequence of actions, the "starting point" of the form making process, the existing approaches to architectural form making are divided into three main groups:

1) Functional approach: this approach includes methods in which the organization of the function is primary. It begins with the form making algorithm of the building, and its features are embodied in the form and image of the building.

2) Image-based approach: this approach includes methods in which the image of the building is primary, where the embodiment process of an architectural form begins with it, such that all other subsystems of the building are subordinated.

3) Generative approach: this includes methods in which the material is primary and its properties determine the sequence of morphogenesis, as well as the final shape of the building.

A detailed analysis of the architectural forms enabled the clarification and determination of the peculiarities involved in applying existing methods, as well as identifying the varieties of image-based methods used in landform architecture. Among these image-based methods, we identified the natural "mimicry,"and metaphorical methods, including the image-based and combinatorial methods.

\section{IMAGE-BASED METHODS IN ARCHITECTURAL FORM MAKING OF BUILDINGS}

Image-based methods of architectural form making were poorly studied in Soviet and Ukrainian $[41,47,48]$ architectural theories, where rigid conventions of the functional method and formal compositional school of constructivists of the twentieth century (20-30's) were observed, both in architecture and in architectural education. However, in the Ukrainian theory sculptural, image-based and metaphorical methods were defined. Every method was characterized with a distinct professional thinking approach of the architect, of which the main principle involves beginning the creative process of developing the form "from the outside to theinside", i.e., from the originally conceived image-symbolic form of an architectural object to its embodiment through other subsystems of the building. In addition, this indicates that the functional and construction structures, as well as the TDC of the building, are consistently in accordance with the original design concept during the design process. The expressiveness of the building, in turn, depends on the individual outlook of the owner, their aesthetic values and ideals, social or ideological function of the building, attitude to the environment, including other factors and prerequisites of architectural design [41, p. 254]. The architect's goal is to create expressive architectural objects that become symbolic buildings with semantic connotations. Our analysis demonstrated that in the national theory, we are discussing the same method of form making, but within different architectural styles and directions.

In world practice, some researchers have distinguished metaphorical architecture, which employs analogies and metaphors as the main source of inspiration in the development of building compositions. Basil Al Bayati, whose works are a blend of the East and West, is one of the most famous representatives of metaphorical architecture [49]. The most striking objects designed via the metaphorical method are usually related to the artistic avant-garde of the 1920-1930 expressionism, which opposed the functionalism of 1920-1930 insearch of the means of expressiveness and orientation for the active plasticity of forms. The images of expressionist constructions (E. Mendelsohn, G. Peltzig, F. Heger, etc.) were built in collaboration with the forms of technology or organic nature, and a symbolic image was often present in them. Expressionist ideas were further developed in the architecture of Western countries in the 1960s of neo-expressionism, when architecture, in its plastic and symbolic compositions, began to resemble sculptures. The most famous sculpture buildings of this period include: 1) Sydney Opera House (1956-1973, architect J. Utzon), in the form of which the author sought to recreate the image of sailing vessels (Figure 1); 2) J. Kennedy Airport in New York (1956-1962, architect E. Saarinen), whose construction was dictated by the symbolic artistic image of a flying bird and not by the requirements of the function or technology of construction; and 3) Restaurant Los Manantiales, Xochimilco in Mexico City (1958, 
architect F. Candela), whose expressive shape was that of a shell in the form of a stylized flower socket. Today, owing to the possibilities of computer and construction technologies in the world of architecture, the search for formal aesthetic approaches is actively ongoing to increase the image-based role of architecture, thus expanding and enriching the arsenal of architectural forms (S. Kalatrava, F. Gary, Z. Hadid, P. Schumacher, K. Kuma, etc.).

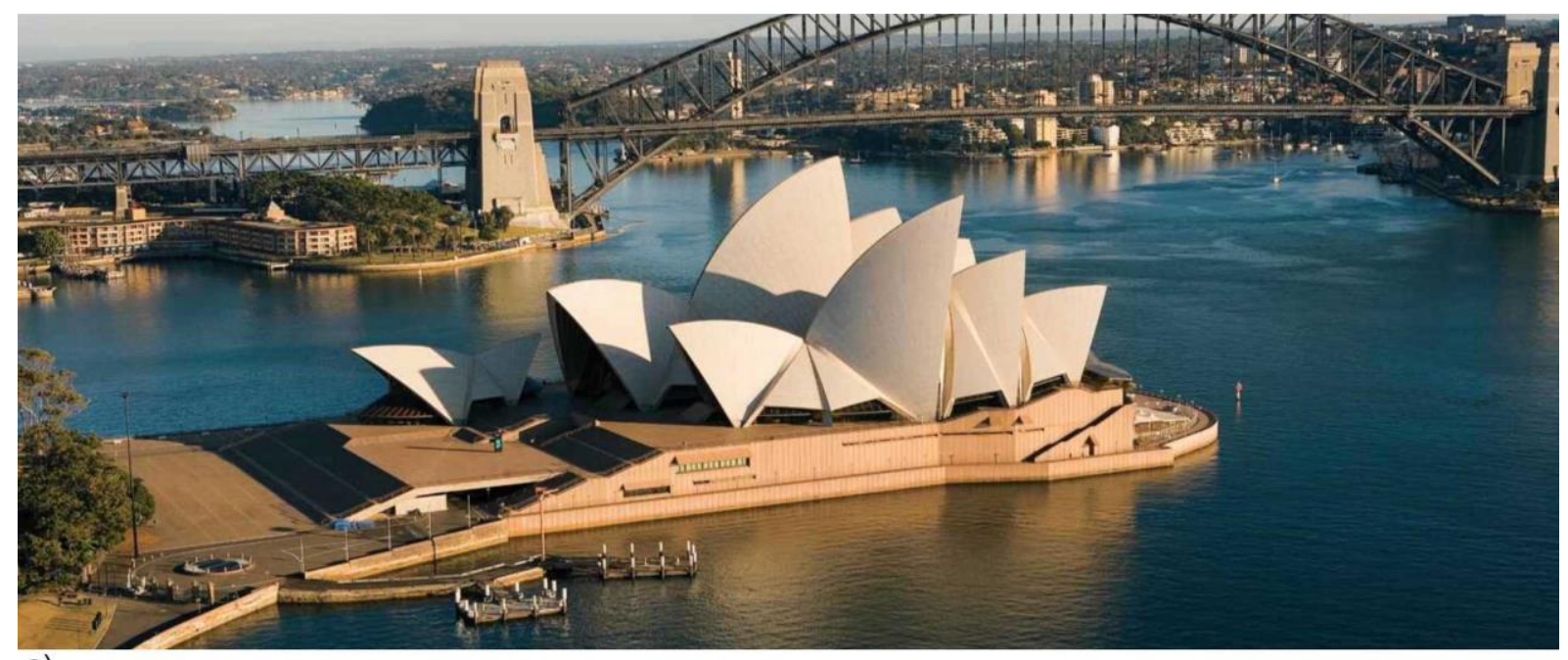

a)
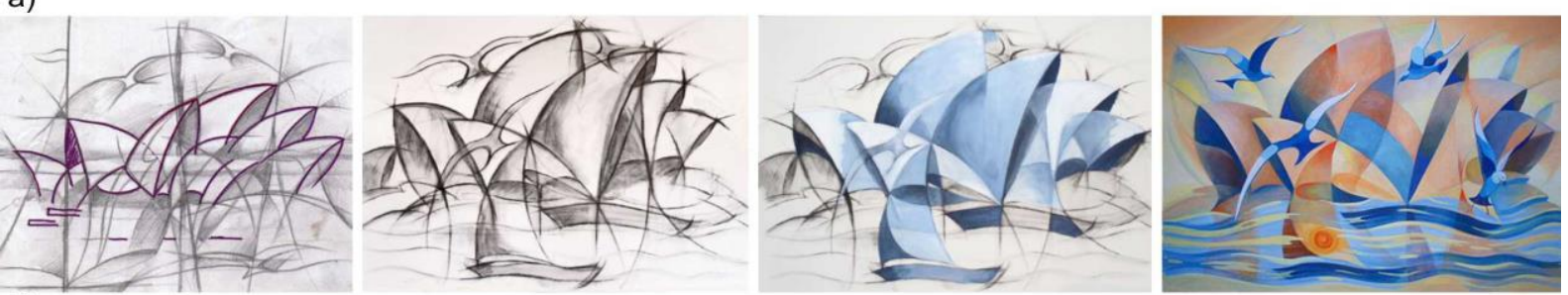

b)

Figure 1. Building image idea inspired by sailing vessels. a) Sydney Opera House, J. Utzon, 1973, Sydney, photo S. Valadi; b) Process of creating a picture by J. Duell, inspired by the image of the Sydney Opera House. Author J. Duell, 2007

The analysis of modern architecture objects allowed us to clarify the features of image-based methods, as outlined below:

- The image of the building is primary. The process of creative morphogenesis begins with an idea of the artistic image of a building, which is embodied via TDC, and the functional, spatial, and structural subsystems, as well as other subsystems of the building are subordinate to the external form.

- Transference is the main method of form making, which involvesborrowing the prototype form or its features for a new building.

- As the initial prototype of the form (in Basil Al Bayati's version- source domain), the following may be used to develop the main idea of the building's image and final form (target domain): nature (zoomorphism, floromorphism, fractal phenomena of nature), people (anthropomorphism), symbols and signs, cultural and religious values, as well astechnical and other objects of human activity and history.

The transference of forms and properties, which originates from the ancient Greek principle of "mimesis" (imitation), has a relatively wide and varied interpretation in modern theory, and is the basis for the continuous development of applying the biological criteria of life in architecture (Gruber P., [55]). Transference can be carried out in different forms, namely, the use of one prototype, form combination of different prototypes, transference of prototype form designs, transferring gone or more properties of the prototype, and applying several types of transference and prototypes simultaneously. Transference provides a different degree of similarity between the new form and prototype, depending on the different degrees of inheritance of the original prototype, from isomorphism to metaphor. Isomorphism is a literal translation and direct resemblance to the visual image of the original prototype in a new building.

Kuznietsova, Y, Osychenko, $\mathrm{H}$ 
In contrast, the development of the architectural metaphor is based on the study of the structure and principle of the original prototype, which enabled its appearance in various image-based associations. Based on this, the stylization, generalization, and schematization of the original prototype's shape is carried out to translate it into an associative TDC (associative model of the object with direct access to the design of the architectural object).

Generalization of form involves the abolition and simplification of details, as well as the identification of the most distinctive features in objects and phenomena and the simplification of the form's structure to convey the essence of the object (Figure 2). Various forms of generalization exist:
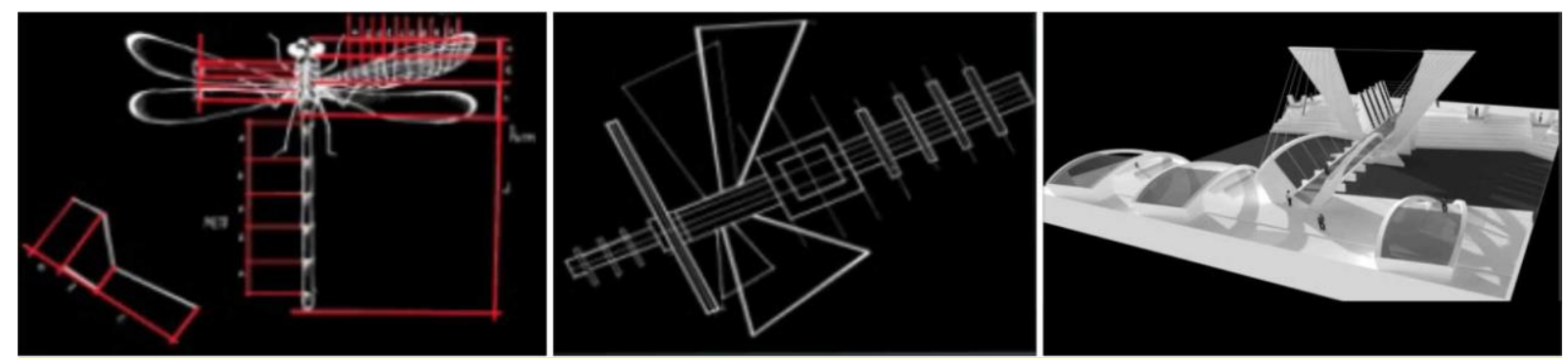

Figure 2. Stylization of a natural form and its transference onto an architectural object. Source [56]

- varying degrees of exaggeration or distortion of the prototype's characteristic features to create an abstraction;

- dominance of one characteristic feature of the object, mitigation, and rejection of other features;

- geometric generalization of the object (within the form, with the change in shape and simplification of the design, transformation from a volumetric form into a plane, change in the characteristic of the form into a more decorative or ornamental characteristic, etc.);

- silhouette generalization of the form (prototype form silhouette is used, prototype configuration in plan);

- sign generalization (simplification, conversion of the form into a sign or symbol).

The presence of architectural metaphor provides the architectural object with ambiguity and expressiveness, and the metaphor acts as a medium of communication. It should be noted that metaphor is a method of semantic construction, aimed at transmitting an image-based impression in an associative form and not at reproducing the prototype objects themselves. Finally, metaphors are conceptual, they are not the works themselves, but mental images... That's the difference between reality and perception" [50, p.4]. Owing to its high degree of abstraction, metaphorical architecture works allow different interpretations, misunderstandings, and various translations.

\section{FORM-MAKING METHODS IN LANDFORM ARCHITECTURE}

A significant number of buildings whose form making processes involved the use of image-based methods have been identified in landform architecture. Various morphotypes of the natural landscape were used as the original prototype. There are several ways of making the landform of architectural buildings, namely,creating an artificial convex-shaped landscape ona flat terrain, where the building forms a new topography and complicates the existing one; embedding the building in the existing slope, where the building becomes a continuation and complication of the existing topography; deepening the building below the surface of the ground on a relatively flat relief (the building "disappears" in the soil layer); and combining different methods. It has been determined that, although it remains within the main features, form making in landform architecture exhibits a number of specific features, which enableseasy identification, depending on the degree at which the new form is similar to the original prototype, including the natural «mimicry», metaphorical, image-based, and combinatorial methods.

\subsection{Natural „mimicry“ method}

Natural "mimicry" is a form-making methodthatcompletely inherits the prototype's external shape (Figure 3). Both the natural and artificially transformed landscapes (the traditional cultural landscape of the terrain but with the predominance of natural components) can be used as a prototype.

Kuznietsova, Y, Osychenko, $\mathrm{H}$ 


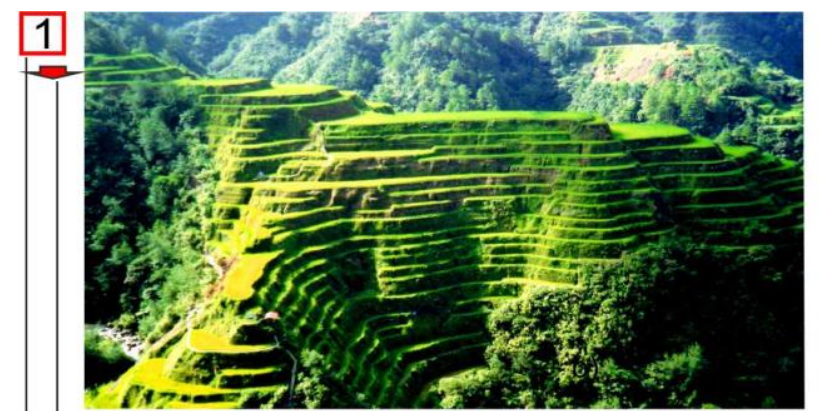

a)

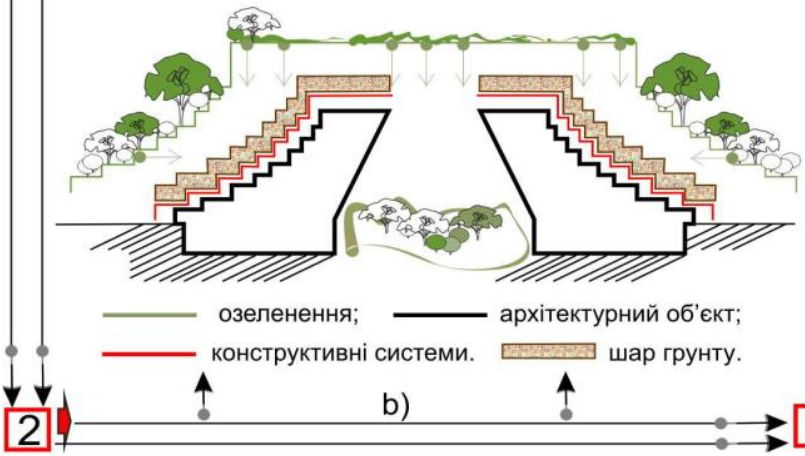

Figure 3. Natural «mimicry» method in architectural form making: 1) Image idea, original prototype; 2) Implementation method; 3) Finished architectural form; a) Banaue Rice Terraces of Ifugao Philippines, photo dais / Fotolia; b) Author's own resources; c) Project Worldbridge Trade and Investment Center, USA, E. Ambasz, Source: [57]

Method peculiarities:

- The main principle of form making is the isomorphism of the original prototype and new form.

- The basic methods of form making are geoplastics (creation and articulation of artificial relief) and transference of material from the prototype (soil with landscaping), which also provides the transference of color and texture properties from the original prototype to the target form.

- The TDC of a building "disappears" as the building is covered with a layer of soil. All other subsystems of the building are secondary and ensure its functioning.

- Soil with vegetation acts as an external enclosure and decorating material of the entire form of the building (or parts thereof) or additional shell. The shell can take its own shape or accentuate that of the building, thus defining another principle of form making- the independence of the object's final image from all subsystems of the building.

Both the orthogonal and non-linear shapes are adopted as the basic forms of the building. The lower horizontal base plane remains at ground level or recedes, but in allcases, the tactile interaction of the building with the ground surface, as well as addressingthe "detachment" of the building roof from the ground, is observed.

- The facades on the walls partially or completely disappear as independent projections under the soil layer and flow into the green roof. The archetypal base planes of the building are combined. There is a

"disappearance" of the building under a layer of soil with vegetation and the emergence of a new shape, which can imitate the shape of natural landscapes (Figure 4): slopes, hilly terrain, craters, river valleys, hollows, basin, hills, etc.

The methods of building integration with the natural environment are determined: geoplastics, green roof, landscaping of combined baselines, combination of approaches, and arrangement of ponds and gardens in the courtyards. By mimicking the shapes of a natural landscape, landscaping of base planes, the object is completely "dissolved" in the environment. 

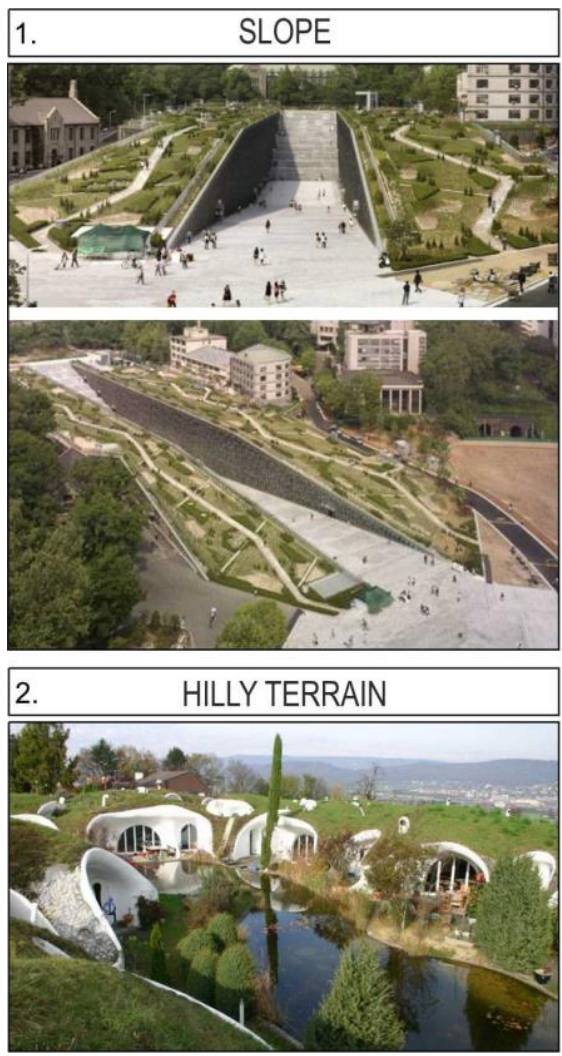
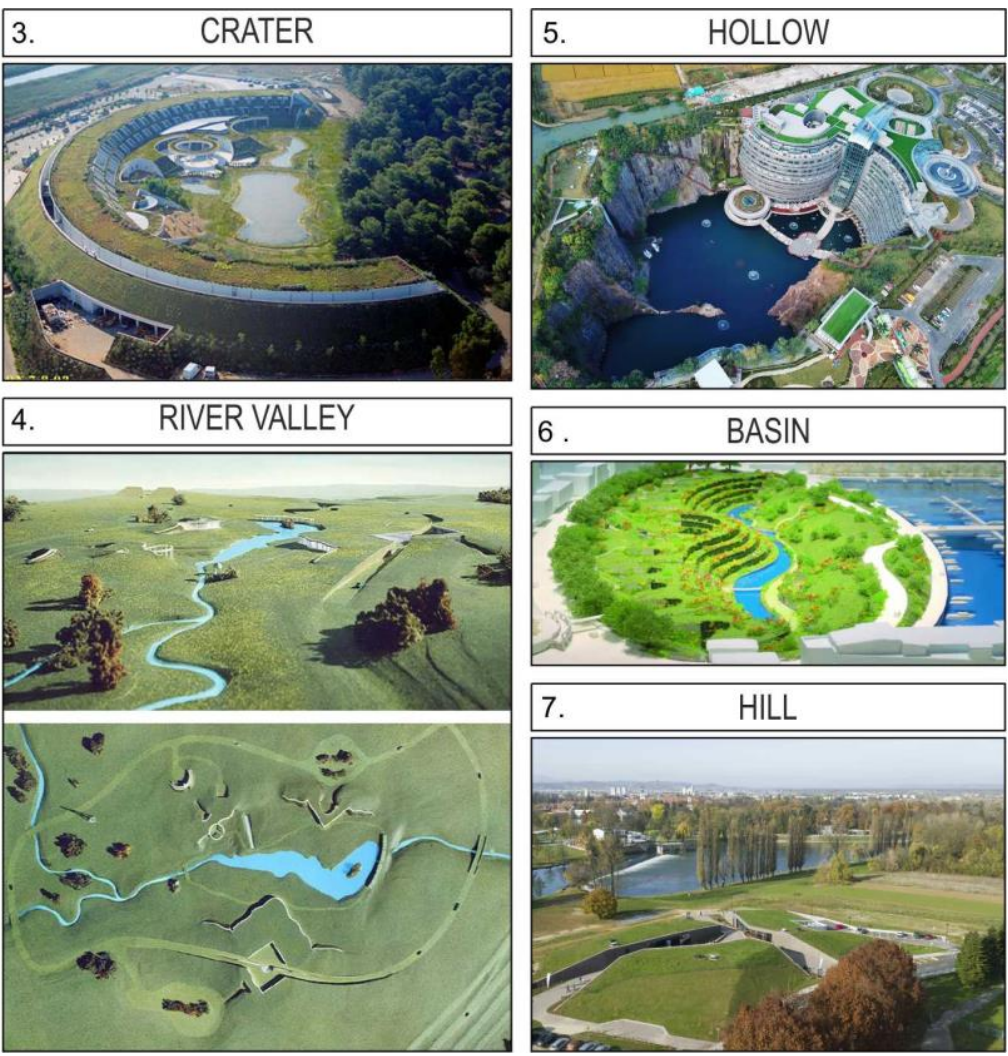

Figure 4. Form imitation of a natural landscape via the «natural mimicry» method: 1) Ewha University Underground Campus, South Korea, Dominic Perrault [58]; 2) Earth house estate lättenstrasse, Switzerland, P. Vetsch. Source: erdhaus.ch; 3) Nichil obihiro department store, E. Ambasz [57]; 4) Schlumberberg Research Laboratories, USA, E. Ambasz [58]; 5) Shimao Quarry Hotel, China, M. Yohman, photo VCC via Getty Images. 6) Monte Carlo public park and residences, Monte Carlo, 1998, E. Ambasz [57]; 7) Freshwater aquarium and river museum, Croatia, 3LHD, photo by M. Bernfest.

The creative credo of the architect, Emilio Ambasz, is considering buildingsas landscapes. In all his architectural projects, he has consistently developed the principles of environmental architecture, which he views in a peculiar, philosophical, and poetic way. In his essay My credo (1991), he says, "... I believe that the real task of architecture is not only to solve rational functional problems, but also to create a favorable living environment." In one of his projects, a home in Cordoba, he was actually attempted to eliminate architecture. The only thing he retained is a facade that plays the role of a mask, which is a surrogate of architecture. Here, the architectural form disappearsas the natural landscape becomes more prominent. The author states that via this technique, he rhetorically excluded architecture as a cultural and historical phenomenon and returned to the original understanding of housing [1]. E. Ambasz's creativity is based on the principle of abandoning standard architecture as he creates architectural objects that are both present and missing. The buildings of the Schlum-Berberg Science Laboratories (Figure 4), USA, are located along a line that imitates river beds and recasts images of drifting shores. Most of the buildings are immersed in soil and covered with a layer of soil via landscaping. Other examples of his work, where he creates natural landscapes, include a public park project, Monte Carlo (figures 4), Villa Casa de Retiro Espiritual near Seville (1975), Leo Castelli House, East Hampton (1980).

The natural "mimicry"method is widespread in buildings outside the city in natural and technocentric environments because it allows the rehabilitation of degraded territories. Owing to the applied method, in the work with the existing relief, it is possible to carry out plastic treatment of sometimes absolutely distinct differences in the topography of the terrain. 


\subsection{Metaphorical method}

The metaphorical method (Figure 5) is a form-making method of landform architecture buildings that involves stylizing forms of natural landscapes rather than copying them directly. We identified three types of transference from the original prototype to the target form:

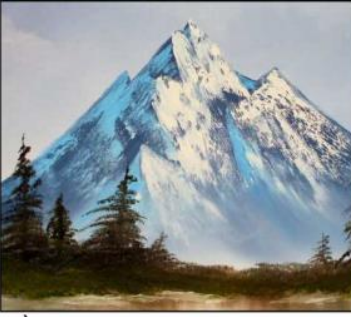

a)

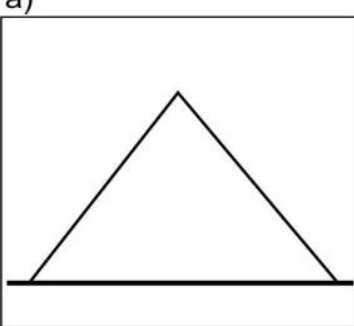

b)
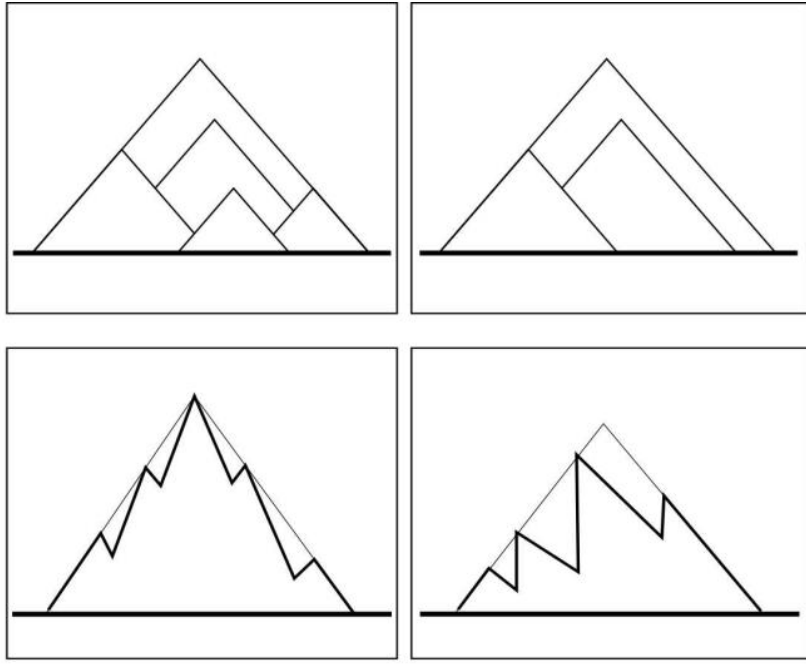
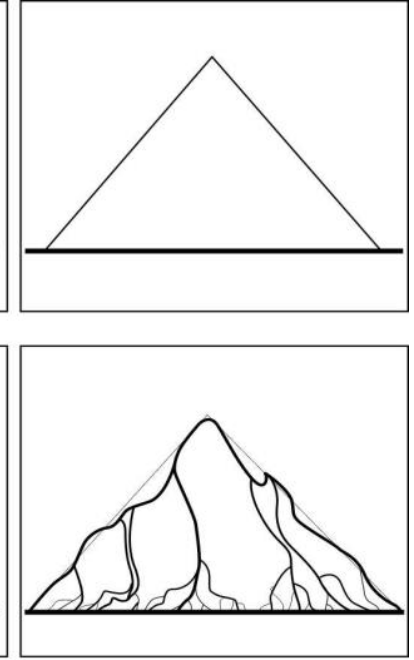

Figure 5. Metaphorical method: a): Form simplification: prototype, photo by Zh. Ptitsyn; other author's resources; b) Stylization: author's resources

1) Form stylization owing to the geometric generalization of the original prototype (within the form, with a change in the nature of the form to become more decorative or ornamental, etc.). Stylization includes the creative processing and modification of the original prototype's form or prototypes with the greatest artistic generalizations within certain sign or style systems.

The composition of the New Moesgaard Museum (Figure 6) in Denmark (arch. H. Larsen) impressed with its
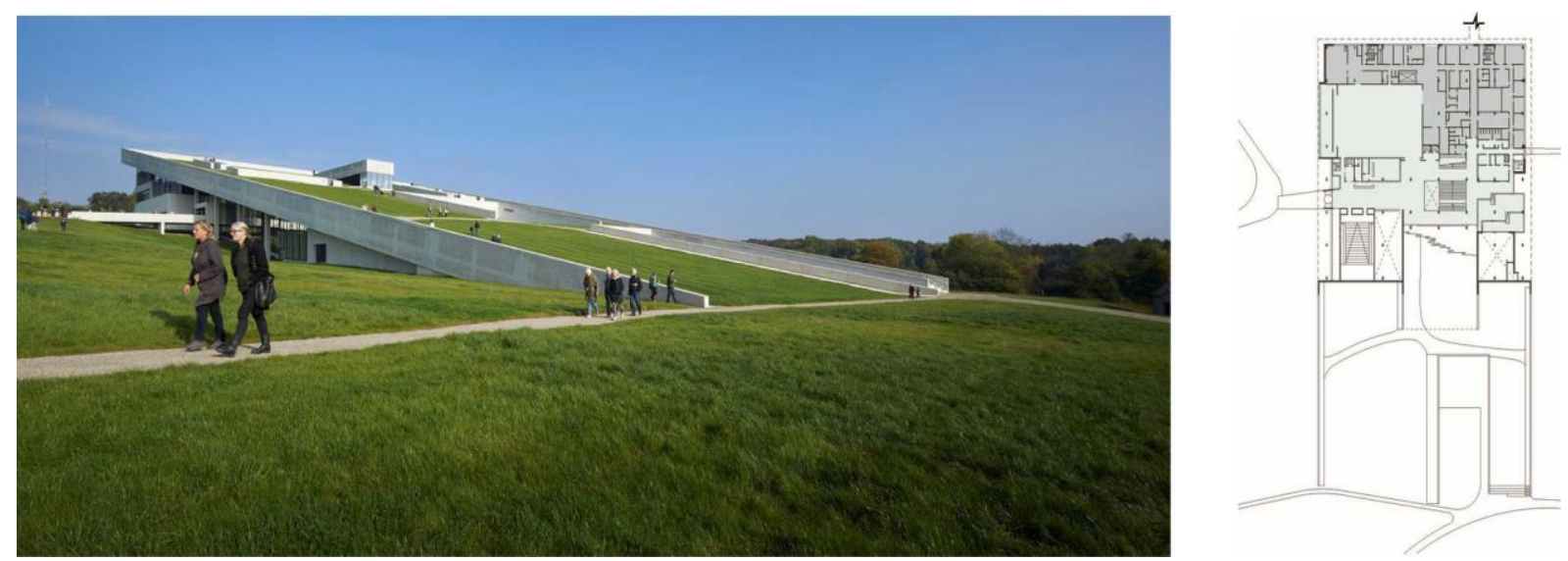

Figure 6. New Moesgaard Museum, Denmark, H. Larsen: a) General viewPhoto by M. Schubert; b) Building plan [59]

powerful sloping green roof that growsout of the landscape to form a geometrically correct slope. In the summer, the roof of the building is used for taking walks, barbecues and picnics, open-air lectures, public holidays, whereas in the winter, when it snows, it turns into a slide. The three outstanding facades of the compact rectangular building are functionally and concisely developed in the best traditions of modernism, which involves the use of abstract basic form for a building with pure geometry, lack of decor, minimum number of details, preservation of archetypes of basic planes of the building, and continuous glazing of facades. The three floors of Kuznietsova, Y, Osychenko, $\mathrm{H}$ 
the building haveterraces under an artificial slope, and similar to archeological excavations, the interiors gradually open to courtyards and exhibition halls, which reveal layers of history that span the lost cities and cultures.

The peculiarities of the artistic code of postmodern architecture (dialog, complexity, contradiction, rhizome, confusion, collage, palimpsest, etc.) transform buildings into complex multi-level urban topographies. Forms of building and relief, competing layers, and floors, as well as place and non-place, which in architecture traditionally oppose each other, merge into a single palimpsest in the building of the Giant Campus by Morphosis (China) (Figure 7). The green hilly roof of the
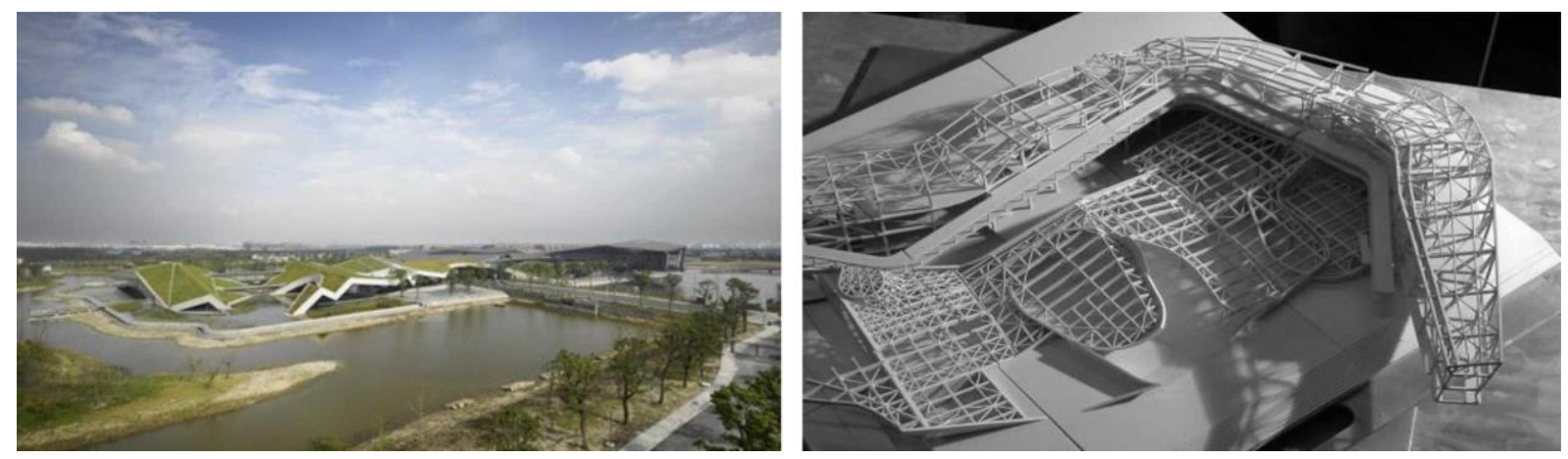

Figure 7. a) Giant interactive group headquarters, China, Morphosis Architects, 2010. Photo: morphosis. com; b) Models by morphosis.com

building, which is part of the landscape it originates from, combines architecture with topography and the surrounding landscape. The Seattle art museum Olympic sculpture park creates a landscape for art, forms a continuous z-shaped "green" platform, and descends from the city to the water, taking advantage of the terrain and Elliott Bay. The platform rises above existing roads to restore the city's connection with the pond (Figure 8).
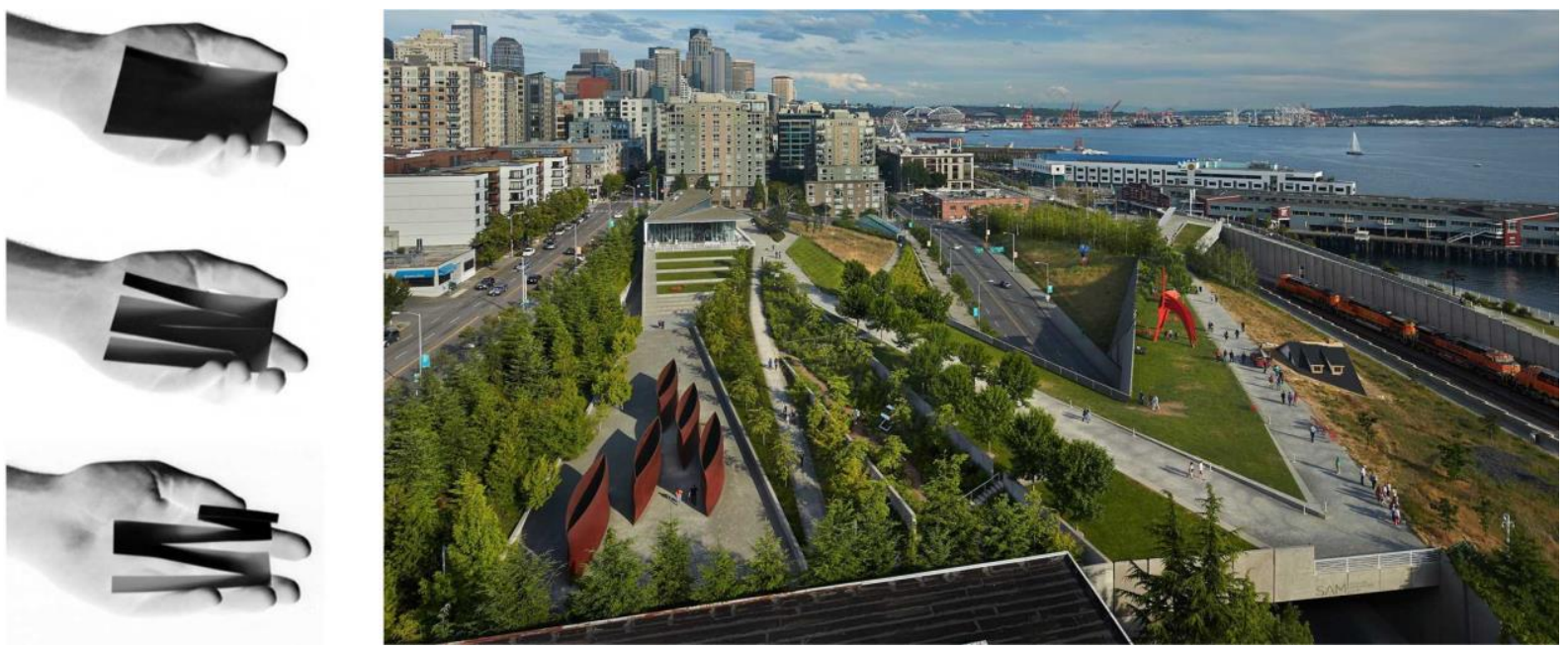

Figure 8. Olympic Sculpturepark, USA, Weiss/ Manfredi. Models from [60]. Photo B. Benschneider

Deconstructivism is characterized by the poetics of chaos and destruction, which is an appeal to majestic types of natural disasters and forms that "explode," split, and fall to pieces. When stylizing the shape of the prototype by applying the features of deconstructivism, architects employ its inherent complex triangular shapes in the plan and silhouette, dramatic sharp corners, topographic fractures, rejection of straight lines and regular shapes, novel expressive forms (folds, shifts, fractures, cracks, etc.), and decomposition. The idea of the Wenchuan memorial earthquake museum, 2008, China (Figure 9) is based on a symbol that is easy to read: the fracture sharply destroys the calm landscape of green hills, just as seismic activity opens fractureson the ground. The large building is hidden under a layer of soil and green roofsand merges with the surrounding landscape, forming a

Kuznietsova, Y, Osychenko, $\mathrm{H}$ 
green hill, whereas the "fractures" of the landscape provide a link between all areas and blocks of the museum and village.
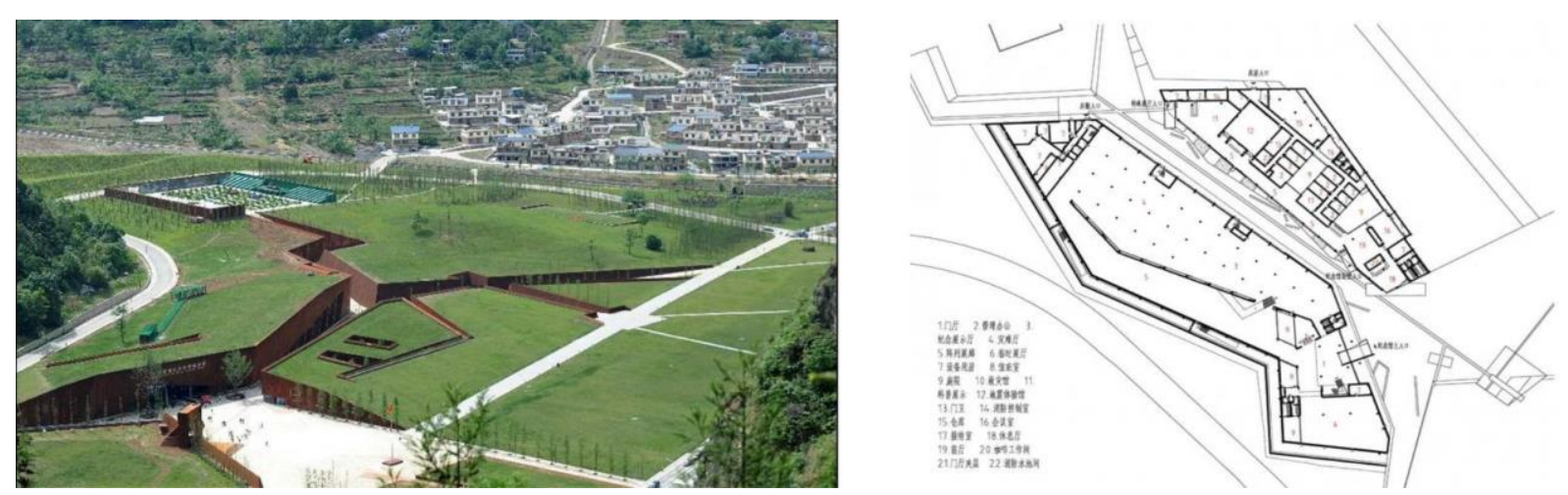

Figure 9. earthquake memorial museum, China, C. Yongjie, 2013. Photo and images C. Yongjie

2) Display of one or more stages of natural landscape morphogenesis in an object form (Figure 10) gives dynamism to the architecture and time dimension.

The TDC of the buildings in the city of culture, Galicia (Spain, architect P. Eisenman, 2013) is inspired by the process of mountain formation during a landslide. This structure is a striking example of the complex dynamic geometry of deconstructivism. According to the original plan, a green roof was envisaged, but currently the roof of the building is not landscaped.

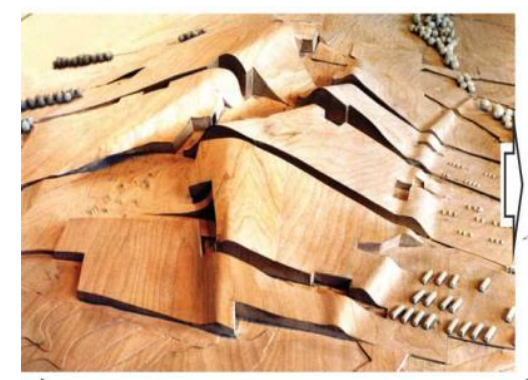

a)

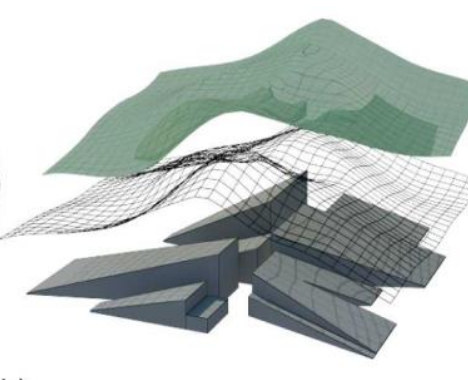

b)

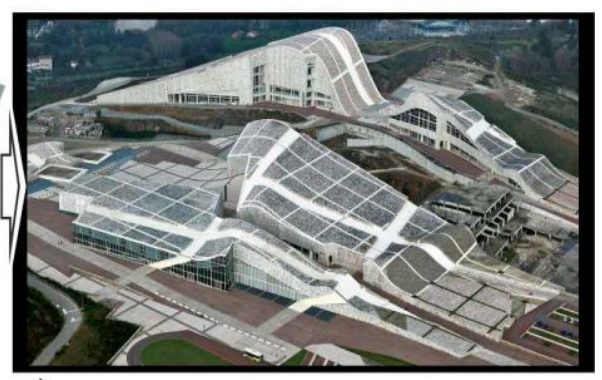

c)

Figure 10. City of culture, Galicia, Spain, P. EISENMAN, 2013: a) Competition model for the City. Image Eisenman Architects; b) Implementation method, author's resources; c) General view. Image Eisenman Architects

3) The use of several types of transference and prototypes is the most common technique in this method. This is usually an additional transference of cultural, regional or historical values, and symbols that doubles the image, increases its emotional impact, and expands its associative range of architecture.

According to the authors' plan for the Zira Island building (Figure 11), Baku (Bjarke Ingels) is a metaphorical embodiment of the seven main peaks of Azerbaijan that are sacralized in the culture of the people. The silhouettes of the buildings are associated not only with mountain peaks, and the varieties of houses- the hills unfold a sequence of stages of mountain morphogenesis. Dynamic expressive architecture aims to identify the position of the young country.

Indesigning the University Library in Indonesia, the authors conceived the building as an earthen architecture that combines the building with its surrounding landscape (architect D. Marshall, 2011). A group of towers rising from a circular grassy mound represents the ancient stone tablets "prasasti"used to record wisdom. The inscriptions 

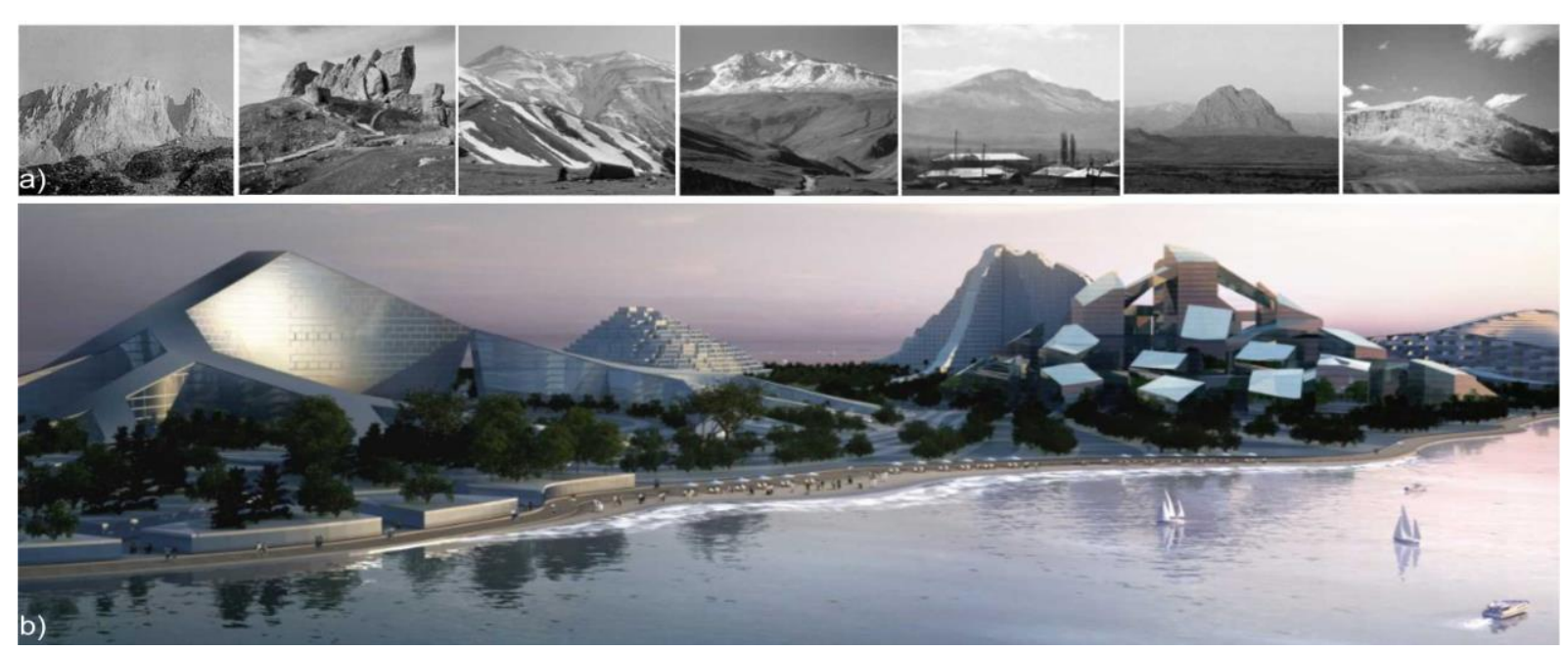

Figure 11. Zira island masterplan, B. Ingels, Azerbaijan, project: a) Prototype, seven peaks of Azerbaijan; b) General view of the project. Image by BIG

themselves are metaphorically expressed by narrow strips of windows, combining history, modernity, nature, and architecture (Figure 12).

Depending on the purpose, the use of natural components in the form making of buildings can be decreased and, in
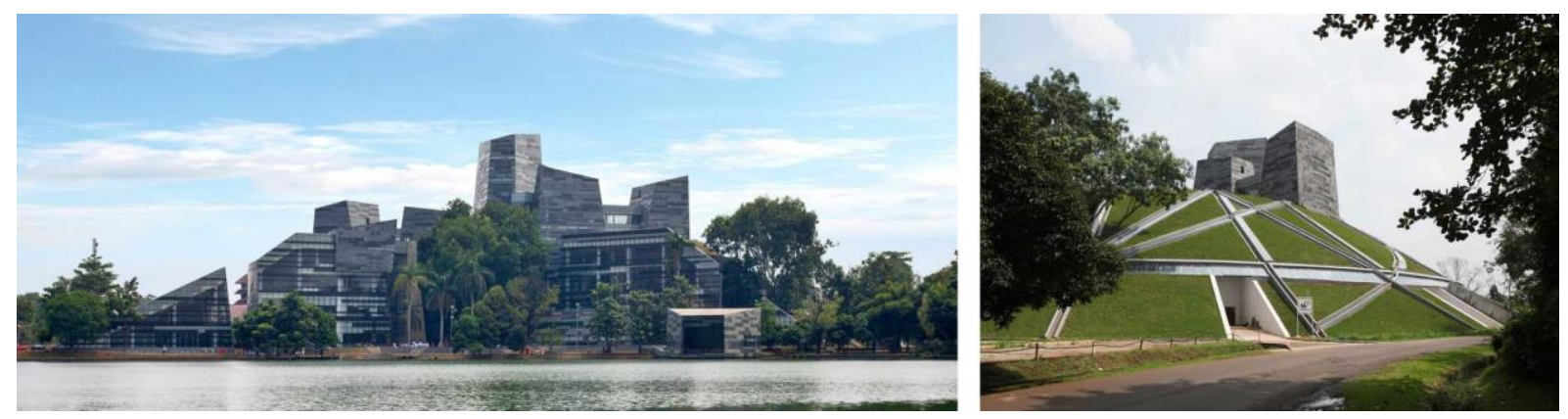

Figure 12. University of Indonesia central library, Indonesia, Denton Corker Marshall, 2011

Photographs: D. Marshall

general, the topography can be reproduced by artificial materials (Figure 13), thus forming a surrogate of a naturallandscape, for example, the project of Pingtang Art Museum, MAD, which is located in the Chinese island closest to Taiwan. 

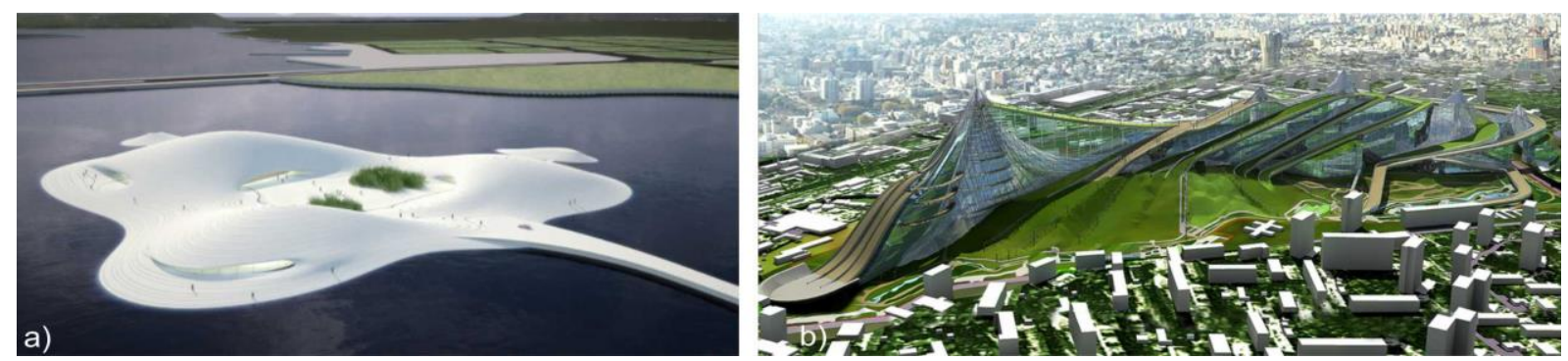

Figure 13. Pingtang Art Museum, MAD, China, 2011: a) General view of the project. Image MAD; b) Allseason sports center, arch. Vasilevsky l., Russia, 2005. Image [61]

The analysis of architectural objects allowed us to determine the features of the metaphorical method:

- The main principle of form making is stylization and generalization, as well as simplifying the form of the original.

- Prototype stylization of forms can be conducted using the features and principles of modernism, deconstructivism, nonlinear architecture, and a combination of different stylistic devices. In addition, artistic codes of postmodernism are also widely used.

- $\quad$ The TDC corresponds to the functional, structural, and spatial subsystems of the building. Both orthogonal and nonlinear forms are used as basic forms of buildings, depending on the accepted sign or style system.

- $\quad$ The archetypal base surfaces of the building are partially or completely combined, and the green roof is combined with the ground.

- $\quad$ The lower horizontal base plane remains at ground level or deepens, but in all cases, the building actively interacts with the earth's surface and creates its own topography.

- $\quad$ The main methods of landscaping are green roofing and landscaping combined base planes.

- The degree of stylization and generalization, size and superficiality of the form, style, number of green roofs, and the author's idea all determine the variety of image-based solutions of buildings. The building becomes a new complex topography, it merges with its topography into a single palimpsest, becomes an architectural metaphor of the natural landscape, and forms an artificial surrogate of the natural landscape.

\subsection{Image-based and combinatorial method}

This method adopts combinatorics as a means of realizing an idea, and its procedure begins with selecting the image idea and natural prototype (Figure 14). The geometric stylization of the shape of the original prototype is preserved to varying degrees. Similar to the metaphorical method, it is possible to use several different types of prototypes. The specificity of this method is determined by its main principle of formation-modularity [62], i.e., the building is a combination of internally interconnected modules (planning-functional and compositional units or elements of form). The primary module can be altered by transforming shapes, resizing, and changing positions in space. 


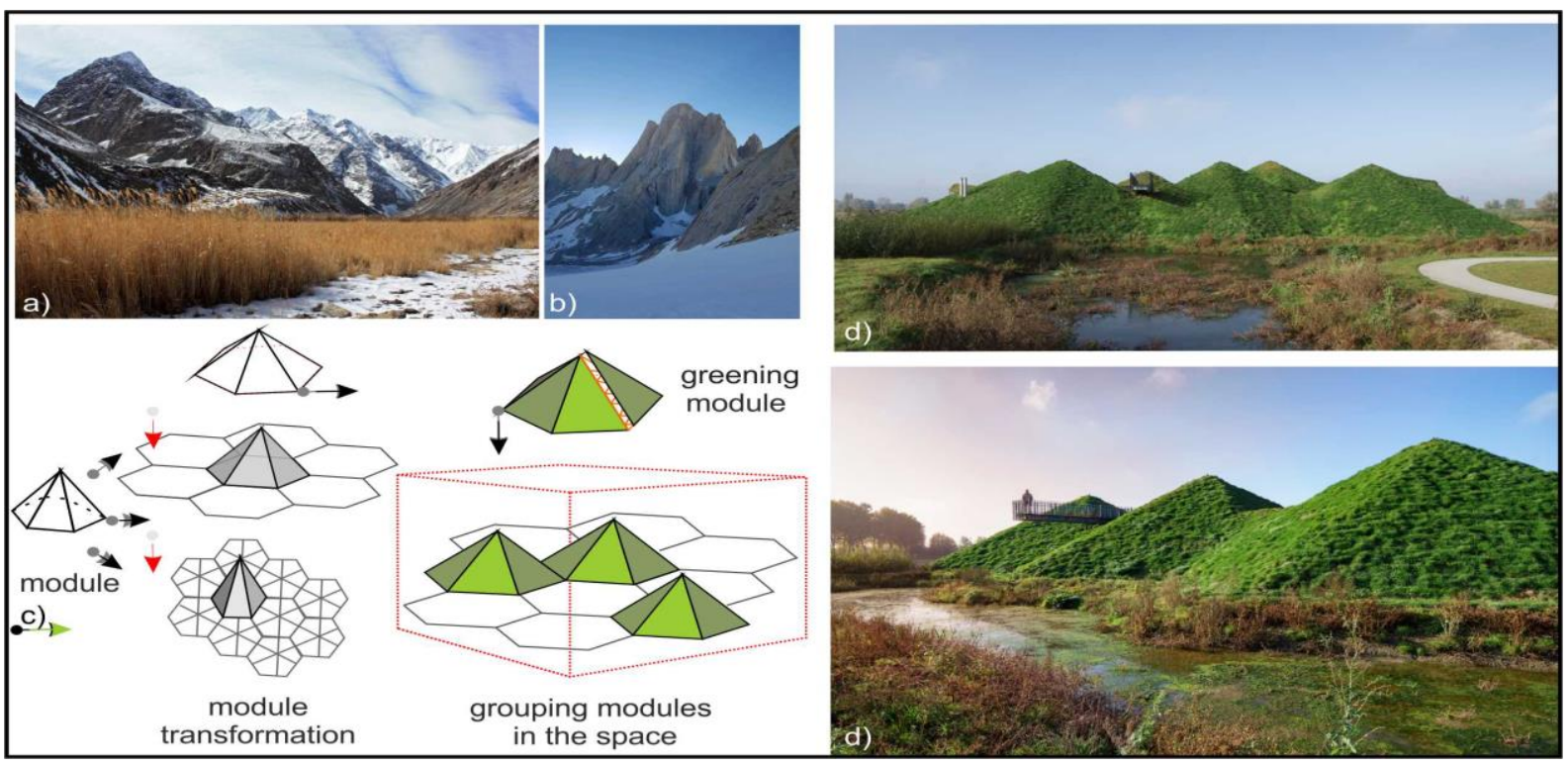

Figure 14. Image-based and combinatorial form making method: Original prototype (mountain range)combinatorics of similar modules- finished form: a) Pamir, Asia, photo by A. Shykhova; b) El Chalten, Patagonia, photo by A. Jelly; c) Procedure of combinatorial modeling of the form, author's resources; d) Biesbosch Museum Island, Studio Makco Vermeulen, Netherlands [63]

The structural order of the architectural composition is often based on a modular grid or lattice (flat grid, three-dimensional grid, and spatial lattice). The typology of grids is based on the principle of their application. Composite, constructive, and functional lattice sare the bases of drawing and TDC, load distribution, and organization and use of space, respectively. Combinatorics can be employed both at the level of one object and that of the urban complex, and in the latter case, the combinatorial module is a separate building.

During the reconstruction of the Biesbosch Museum Island (architect Studio Makco Vermeulen), the original hexagonal functional blocks were preserved. Using a hexagonal spatial grid as an organizing module, a new wing of the building, with a total area of $1000 \mathrm{~m}^{2}$, was added to the southwest. Because modules are represented as relatively independent volumetric and spatial figures, the green and partially glazed pyramids are combined in the volumetric and spatial composition of the building. The expressive sculptural form of the building is perceived as an art landscape, and from the side of the reservoir, the architecture manifests itself in the surrounding landscape owing to the remaining glazed facades (Figure 14d).

\section{CONCLUSIONS}

The author's methodology clarifies the approaches to building form making (functional, generative, and imagebased approaches) and analyzes the image-based approach to architectural design, which is determined by a specific algorithm of form making: from the idea to the finished form of the image. Based on the building analysis, the manifestations of the image-based approach in modern landform architecture were investigated.

Although image-based methods of landform architecture are derived from the image-based approach in general, they have their own peculiarities. They derive their inspiration and forms from the natural landscape and processes of the original prototype's morphogenesis, create a certain extent of their own topography, and adopt natural components (vegetation, soil) in the form making of buildings. A different degree of interaction exists between the artificial form and the natural components in its composition, from the predominance of natural components in the image to the transformation of vegetation to the decoration of the building.

Depending on the transference type of the prototype form and methods of form making, the image-based methods of form making in landform architecture were determined: natural "mimicry," metaphorical", image-based and combinatorial methods. The natural "mimicry" method is determined by the isomorphism of the original prototype and target shape, which is enhanced by the transfer of material (soil with vegetation), color, and texture 
properties from the prototype to the building. The main principles of the metaphorical method are generalization, stylization, and simplification of the original prototype's forms when transferred to the target form. A metaphor implies a wider range of associated meanings and abstractions of the building image. The following types of metaphorical transfers from the original prototype were determined: stylization owing to geometric generalization of the original prototype's form, reflection in the form of an object of one or more stages of morphogenesis of the natural landscape, application of several types of transference and prototypes. The metaphorical method of landform architecture demonstrates a variety of methods applied in modernist, postmodernist, and nonlinear paradigms of form making. The image-based and combinatorial method combines the geometric stylization of the original prototype's form with the modularity of the target form, which brings the building closer to art landscapes. The main methods of form making were also determined. They are a combination of identical or similar elements and modules with lattice and layered combinatorics of the elements of facade planes. In all these methods, there is a complete or partial rejection of the archetypes in the basic planes of the building: the walls and roof are combined to become the exterior "floor."

The core of modern construction is changing. Thousands of years ago, when man needed shelter, nature provided understanding on how to solve this challenge. Today, with vast construction experience and modern technology, the modern man attempts to recreate the lost connection with the environment, reduce the visual impact of buildings on nature, compensate the lack of natural areas, and achieve natural balance. Objects designed via the natural "mimicry" method show that to achieve this, architects are capable of "mimicry" and abandoning the "holy of holies" of its profession - the architectural form, by deliberately designing the partial and complete visual disappearance of the building under the soil layer.

We also determined a variety of specific manifestations of image-based form making methods, diffusion of methods, their techniques, and paradigms of form making. In fact, the method proposed is not a single or specially designed "supermethod" that claims to be a complete and final formulation of the "secret of creativity," but on the contrary, it is a set of all possible methods and ways of architectural work considered in their most general and fundamental expressions. Therefore, it is important to study different models of creativity, approaches, and methods as they create the completepotential of the architectural profession, provide instrumental flexibility, variability, and adequacy of design solutions.

\section{Acknowledgments}

This research was carried out according to the study by O.M. Beketov, National University of Urban Economy in Kharkiv, on the scientific theme: "Spatial tendencies of architectural environment form making in the development conditions and latest technologies of architectural education" (State Register No. 0117U004380).

\section{References}

[1] Ambasz, E. et al. 2017: Emilio Ambasz: Emerging Nature: Precursor of Architecture and Design, Lars Müller Publishers, Switzerland

[2] Allen, S. et al. 2011: Landform building: architecture's new terrain, Allen, S.; Mcquade, M. Eds., Lars Müller Publishers, Switzerland

[3] Balmori, D.; Sanders J. 2011: Groundwork: between landscape and architecture, Monacelli Press, New York

[4] Jencks, C. 1997: The Architecture of the Jumping Universe, Academy, London \& NY

[5] Jodidio, P. 2018: Green Architecture, TASCHEN

[6] Leatherbarrow, D. 2004: Topographical Stories: Studies in Landscape and Architecture, University of Pennsylvania Press, Philadelphia

[7] Sterling, P; Carmody J.; Ellison T. 1983: Designing buried dwellings, M.: Stroiizdat, Moscow (in Russian)

[8] Wines, J. 2000: Green Architecture, TASCHEN

[9] Xiaoning, H. 2005: Landform architecture, Architecture Southeast University, China (in Chinesse)

[10] Xiaoning, H. 2009: Building Design Integrating Landscapes, CNPeReading, China (in Chinesse)

[11] Wang, Yi. 2015: Landform Architecture As Reconnecting Presence For Campus Complex Design, Masters Theses, University of Massachusetts Amherst.

[12] Zambelli, M. 2006: Landform Architecture, Edilstampa, Roma (in Italian)

[13] Wright, F. 1939: An organic architecture: the architecture of democracy, Lund Humphries, London

Kuznietsova, Y, Osychenko, $\mathrm{H}$ 
[14] Sajmonds, D. 1965: Landshaft i arhitektura, Strojizdat, Moskva (in Russian)

[15] Thomas, R. 2006: Environmental Design and introduction for architectures and engineers, USA

[16] Know, A.; Grondzik, W. 2007: Greenstudio HANDBOOK, Environmental Strategies for Schematic Design, Architectural Press, USA

[17] Luckett, K. 2009: Green roof construction and Maintenance, Mc Graw Hill, USA

[18] Portoghesi, P. 2000: Nature and Architecture, Skira, UK

[19] Nefedov, V. 2012: Gorodskoj landshaftnyj dizajn, Lyubavich, S-Peterburg (in Russian)

[20] Zaslavskaya, A. 2008: Osobennosti organicheskogo podhoda v arhitekture konca XX - nachala XXI veka: diss. kand. arkh.: spets. 18.00.01, Nizhnij Novgorod, 191 s. (in Russian)

[21] Osychenko, H. 2009: Arkhitektura yak chastyna landshaftu. Visnyk XDAAiM. № 6. - S. 98-105 (in Ukrainian)

[22] Chyzhmak, D. 2012: Principi arhitekturno-planuvalnoi organizacii ekologichnih visotnih administrativnihi budivel: diss. kand. arkh.: spets. 18.00.02, Kiïv, 214 s. (in Ukrainian)

[23] Volinets, I. 2017: Osoblivosti viniknennya ta rozvitku ponyattya lendformnosti v arhitekturi, Ivyvska polytekhnyka, Lviv (in Ukrainian)

[24] Logvinov, V. 2009: O prirodointegrirovannoi arkhitekture, Arkhitekturnyi vestnik, 2(107) (in Russian)

[25] Krizhanovskaya, N. 2010: Priemy formirovaniya prirodnointegrirovannoj arhitektury $v$ gorodskoj srede, BGTY, Belgorod (in Russian)

[26] Hordienko, Y. 2011: Printsypy formirovaniya prirodointegrirovannoi arkhitektury: diss. kand. arkh.: spets. 18.00.01, Kharkov, $201 \mathrm{~s}$. (in Ukrainian)

[27] Votinov, M.; Smirnova, O. 2019: Eco-oriented architecture as a means of creating a sustainable urban environment, Electronic Journal of the Faculty of Civil Engineering Osijek-e-GFOS, 18, pp. 1-11, https://doi.org/10.13167/2019.18.1

[28] Murenkova, K. 2017: Lendformnyj podhod v proektirovanie turesticheskih obektov "Zolotoe kolco Altaya" diss. kand. arkh.: spets. 6M042000, Kazahstan, 230 s. (in Kazakhstanian)

[29] Tomkowicz, B. 2019: Przekształcenia przestrzeni dachów, Politechnika Krakowska, Poland

[30] Gała-Walczowska, M. 2014: Architektura domu jednorodzinnego w krajobrazie: praca doktorska, Kraków, $284 \mathrm{~s}$.

[31] Kusinska, E. 2008: Woda w założeniach architektoniczno - urbanistycznych: praca doktorska, Kraków, $200 \mathrm{~s}$.

[32] Haupt, P. 2017: Zielone dachy - rozbudowana miejska przestrzeń rekreacyjna, Verlag, Erlangen

[33] Kmych, M. 2016: Zielone elewacje w architekturze na przykładzie Chin, PK, Kraków

[34] Rzeszotarska-Pałka M. 2015: Gra w zielone - zieleń w architekturze, Space and FORM/ Przestrzeń Szczecin, 24 (2), pp. 177-190.

[35] Zbašnik-Senegaènik, M.; Kuzman, M. 2014: Interpretacije organske arhitekture, Prostor, Zagreb

[36] Mustapić, M.; Vlahov, A. 2015: Važnost dizajna u arhitekturi za pozicioniranje hotela na turističkom tržištu, Acta turistica, Croatia

[37] Dobritsyina, I.2004: Ot postmodernizma - k nelineynoy arhitekture: Arhitektura v kontekste sovremennoy filosofii, Moskva (in Russian)

[38] Kashchenko, O. 2013: Formoutvorennj v dizaini ta arkhitekturi na osnovi modelyvannj boiprototupiv: dok. tex. nayk.: spets. 05.01 .03 Kuiv, 318 c. (in Ukrainian)

[39] Lebedev, Yu.; Rabinovich, V. 1990: Arhitekturnaya bionika, Stroyizdat, Moskva (in Russian)

[40] Pronin, E. 2004: Teoreticheskie osnovyi arhitekturnoy kombinatoriki, Arhitektura-S, Moskva (in Russian)

[41] Shapoval, N. 2008: Osnovy arkhitekturnogo formoutvorennia, Osnova, Kyiv (in Ukrainian)

[42] Architectural Association School of Architecture. Frazer J. Intentionality - The coding of a design concept. https://www.aaschool.ac.uk/, Accessed 15 April 2020

[43] Oxman N. 2010: Structuring Materiality: Design Fabrication of Heterogeneous Materials, Architectural Design, 80 (4), pp.78-85. https://doi.org/10.1002/ad.1110

[44] Schumacher P. 2010: Parametric Diagrams. The Diagrams of Architecture, In The Diagrams of Architecture: AD Reader, Garci, $M($ (Ed.), John Wiley \& Sons.

[45] Terzidis, K. 2008. Algorithmic Complexity: Out of Nowhere. Complexity. Design Strategy and World View, Birkhäuser Verlag AG, Berlin, Germany.

[46] Ching, F. 2007: Architecture: Form, Space, and Order, John Wiley \& Sons, Canada

[47] Tits, A. 1976: Osnovy arkhitekturnoi kompozitsii i proektirovania, Vyshcha shkola, Ukraine (in Russian)

Kuznietsova, Y, Osychenko, $\mathrm{H}$ 
[48] Ikonnikov A., Stepanov, G. 1971: Osnovyi arhitekturnoy kompozitsii. Moskva, Stroyizdat (in Russian)

[49] Bayati, B. 2011: The Age of Metaphors, Fabulist, United Kingdom

[50] Fez-Barringten, B. 2011: Anyflip. Metaphor issues of "architeture is art" stasis, http://anyflip.com/crbk/qzmv, Accessed 28 April 2020

[51] Karatani, K. 1995: Architecture as metaphor, The MIT Press, United Kingdom

[52] Ortony, A. 1979: The Role of Similarity in Similes and Metaphor, Cambridge University Press, London

[53] Zambelli, M.2019: La mente nel Progetto. L'analogia e la metafora nell'architettura e nel design, Dip. di Architettura (Firenze) (in Italian)

[54] Gabrichevskii, A. 2002: Morfologij iskustva, Agraf, Moskva (in Russian)

[55] Gruber, P. 2012: Biomimetic in architecture, Springer, Wien/NewYork.

[56] Chernichenko A. 2015: Metod preobrazovania prirodnoi formy v assotsyativnuiu model arkhitekturnogo obiekta, Rostov-na-Dony (in Russian)

[57] Emilio Ambasz \& Associates Inc. Portfolio. Buildings. https://www.ambasz.com/buildings, Accessed 30 April 2020

[58] Arcspace. Ewha Woman's University. https://arcspace.com/feature/ewha-womans-university/, Accessed 25 April 2020

[59] ArchDaily. Projects. Museum. Denmark. Moesgaard Museum/ Henning Larsen. https://www.archdaily.com/590484/moesgaard-museum-henning-larsen-architects/, Accessed 25 April 2020

[60] Weiss/Manfredi. Projects. Seattle Art Museum: Olympic Sculpture Park. http://www.weissmanfredi.com/project/seattle-art-museum-olympic-sculpture-park, Accessed 20 April 2020

[61] Archinfo. Projects. The buildings. Smart city, http://www.archinfo.ru/publications/item/41, Accessed 29 April 2020

[62] Kuznietsova, Y.; Osychenko, H. 2020: Combinatorial technique and means of integrating nature into an architectural form, Space and FORM, Szczecin, 41, pp. 43-54. https://doi.org/10.21005/pif.2020.41.B-03

[63] Studiomarcovermeulen. Baesbosch Museumeiland, https://marcovermeulen.eul, Accessed 28 April 2020

Please cite this article as: Kuznietsova, Y.; Osychenko, H.: Form-making methods in landform architecture, Electronic Journal of the Faculty of Civil Engineering Osijek-e-GFOS, 2020, 21, pp. 1-17, https://doi.org/10.13167/2020.21.1 